\title{
YALIN DÜŞÜNCE UYGULAMASI: HASTANELERDE DEĞER KATMAYAN FAALIYYETLERINN ORTADAN KALDIRILMASI
}

\author{
İrfan ÖZEN*
}

\section{Özet}

Hastanelerde teşhis, tedavi veya diğer hizmetlerin en kısa sürede ve en uygun şekilde hastalara ulaştırılması gerekir. Ancak diğer sektörlerde olduğu gibi sağlık sektöründe de hizmet üretim sürecine değer katmayan faaliyetler nedeniyle gecikmeler, aksamalar ve hasta beklentilerine uymayan sonuçlar yaşanmaktadır. Hastanelerde hangi süreçlerin ve işlemlerin hizmet üretimine katkı sağlamadığının, hangi süreçlerin ve işlemlerin katkı sağladığının belirlenmesi, kaynak israfını önlemede önemli avantajlar sağlayacaktır.

Çalışmada, bir kamu hastanesinde değer katmayan faaliyetler ve bu faaliyetlerin ortadan kaldırılmasına ilişkin tespitler ve önerilere yer verilmiştir.

Anahtar Kelimeler: Yalın Düşünce, Yalın Hastane, Değer Analizi, Değer Katmayan Faaliyet, Maliyet Yönetimi.

\section{LEAN THINK APLICATION: ELIMINATION OF NON-VALUE-ADDING ACTIVITIES IN HOSPITALS}

\begin{abstract}
Diagnosis, treatment or other services in hospitals must be delivered to the patients as soon as possible and properly. However, as in other sectors, due to the non value adding activities to the service process in health sector, there have been delays, disruptions and the results that doesn't meet the patients' expectations. Identification of which processes and procedures that don't contribute to the service production in hospitals will provide significant benefits in the prevention of waste of recources.

This study includes non value adding activities in a public hospital and determinations and suggestions respecting eliminations of these activities.
\end{abstract}

Keywords: Lean Thinking, Modest (Lean) Hospital, Value Analysis, Non Value Adding Actvity, Cost Management.

* Muğla Sıtkı Koçman Üniversitesi Datça Kazım Yılmaz MYO Muhasebe Vergi Uyg. Prog. Öğr.Gör. 


\section{Gíriş}

İşletmelerin rekabetini belirleyen temel unsurlar; kalite, maliyet ve zaman olarak sıralanabilir. İşletmeler, rakiplerinden daha kaliteli ve fonksiyonel ürünleri, müşterilerin istedikleri zamanda ve yine müşterilerin beklentilerine uygun bir fiyattan piyasaya sürdüklerinde rekabet avantajı sağlayabilmektedir.

Rekabetin değişen boyutu işletmeleri, dış unsurlardan çok işletme içi unsurlara yöneltmektedir. Bu bağlamda ürünlerin satış fiyatı yerine üretim maliyetlerine odaklanmak daha anlamlı ve önemsenmesi gereken bir faktör haline gelmiștir.

İşletmelerde maliyet, rekabet için temel unsurlardan biri olarak kabul edildiğinde, bu maliyetlerin doğru hesaplanması ve işletme amaçlarına uygun yönetilmesi önemli bir konu haline gelmektedir. Günümüzde maliyetlerin doğru hesaplanması ve yönetilmesi, geleneksel maliyet muhasebesi teknikleriyle mümkün olmaktan çıkmış, ileri maliyet muhasebesi tekniklerinin kullanılması bir gereklilik halini almıştır. Hem maliyetlerin doğru hesaplanmasında, hem de maliyetlerin işletme amaçlarına uygun yönetilmesinde maliyet unsurlarındaki değişimin özellikle dikkate alınması gerekmektedir.

Maliyetlerin rekabet aracı olarak kullanılmasına olanak sağlayan tekniklerden biri faaliyet tabanlı maliyetleme ve faaliyet tabanlı yönetimdir. Faaliyet tabanlı maliyetleme, işletmelerde faaliyetlerin ve süreçlerin analizinde önemli sonuçların elde edilmesine katkı sağlayarak, ilgililerin üretim sürecindeki hangi faaliyetlerin ürünlere değer katıp katmadığını tespit etmesinde önemli bir araç olarak kullanılabilmektedir.

Faaliyetlerin değer katıp katmadığının belirlenmesi sürecinde değer akım haritaları çıkarılmakta ve odaklanılması gereken faaliyetlerin neler olduğu belirlenebilmektedir. Bu çalışmada, bir kamu hastanesinde değer katmayan faaliyetler ve bu faaliyetlerin nasıl ortadan kaldırılacağına ilişkin değerlendirmelere yer verilmiştir.

\section{DEĞER KATMAYAN FAALIYETLER}

Yalın olmayan hizmet süreçlerinde yapılan faaliyetlerin en az \%50'si değer katmayan faaliyetler olduğu belirlenmiştir. Örneğin, Lockheed Martin’de yapılan bir çalışmada satın alma siparişinin verilmesi ile birlikte ürünlerin teslim alınmasına kadar gerçekleştirilen faaliyetlerin \%83'ü değer katmayan faaliyet olarak tespit edilmiştir. Yapılan çalışmalarla elde edilen ampirik verilere göre hizmet süreçlerinin, müşteri bakış açısı ile değer katmayan faaliyetler ile gerçekleştirildiği görülmüş ve hizmetlerin maliyetinin \%30-80’ni bu değer katmayan faaliyetlerden

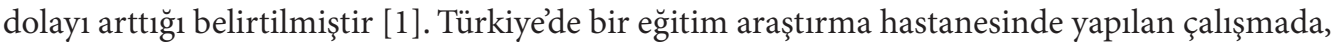
\%42'lik bir israfın olduğu belirlenmiş [2] ve bu oran başka bir eğitim ve araştırma hastanesinde tarafımızdan çalışma sonuçlarıyla benzerlik göstermektedir. 
Yalın düşüncenin amacı, değerin ilk ham maddeden başlayarak, değer yaratma süreci boyunca hiç kesintisiz akıtılarak hızla nihai müşteriye ulaştırılmasıdır. Bunu başarabilmek için tüm değer zincirine bir bütünlük çerçevesinde bakmak, israfları yok etmek ve tüm faaliyetleri müşteri için mükemmel değer oluşturmak amacına yönlendirmek gerekir. Yalın'da israf, bilinen anlamının ötesinde ürün ya da hizmetin kullanıcısına herhangi bir fayda sunmayan, müşterinin fazladan bedel ödemeyi kabul etmeyeceği her şeydir [3].

Değer katmayan faaliyetlerin ortadan kaldırılması işletmelerin sürdürülebilir rekabetine katkı sağlayan yaklaşımlardan biridir. Günümüzde birçok işletmede, üretim ve değer katma faaliyetlerinde önemli değişiklikler olmuştur [4]. Küreselleşen rekabet ortamında değer, işletme süreçlerinin kritik başlangıç noktasıdır ve değer ancak nihai müşteri tarafından tanımlanabilir. Değer tanımının anlamlı olması için müşteri gereksinimlerinin, belli bir zamanda belli bir fiyattan karşılayan bir ürün cinsinden ifade edilmesi gerekir [5].

İşletmelerde yürütülen faaliyetler değer katan faaliyetler ve değer katmayan faaliyetler olarak iki temel başlık altında toplanabilir [6]. Değer katan faaliyetler, müşteri değerine katkı sağlayan ya da işletmenin ihtiyaçlarını karşılayan veya her ikisi birlikte gerçekleştiren faaliyetleri ifade eder [7]. Değer katmayan faaliyetler, kaçınılabilir ve kaçınılamaz faaliyetlerden oluşur.

Değer katan faaliyetler, farklı kaynaklarda çeşitli şekilde açıklanmakla beraber en çok kabul göreni, müşterilerin gözünde değer katan faaliyetler veya faaliyetlerin verimliliğini artıran faaliyetler veya çıktılara doğrudan katkı sağlayan faaliyetler olarak ifade edilmektedir [8]. Değer katmayan faaliyetler, ürün ve hizmetlerin maliyetini artıran ya da piyasa değerine katkı sağlamayan üretim zamanını artıran faaliyetlerdir [9].

İşletmelerde öncelikle ürünün kusursuz bir şekilde üretilmesi için gerekli değer katan faaliyetler belirlenmelidir. Değer katan faaliyetler belirlendikten sonra, işletmelerde değer katmayan faaliyetler belirlenmelidir [10]. Değer katmayan faaliyetler ise müşterinin normalde ödeme yapmak istemediği faaliyetler olarak tanımlanabilir [11]. Değer katmayan faaliyetler, kâr kayıplarına neden olan, zaman, kaynak ya da para israfıdır ve çıktılar düzeyinde gereksiz maliyetlere neden olmaktadır [12].

Değer katmayan faaliyetlerin maliyetlerinin kaynağı, bu maliyetlerin ortaya çıkışında temel etken olan faaliyetlerdir. Bu maliyetler, değer katmayan faaliyetlere ait maliyetlerdir [13].

Değer katan faaliyetler, işletmelerin farklı fonksiyonları esas alınarak belirlenebilir. Üretim işlevi yönünden bakıldığında, mamul ya da hizmet üretim sürecinden çıktı aşamasına ulaşıncaya kadar çeşitli aşamalar vardır. Son aşamada çıktıya ulaşıncaya kadar, sürecin tamamlanması için vazgeçilemeyecek ve süreç için bir değer ifade edecek her faaliyet, çıktıların elde edilmesinde sürece değer katan faaliyettir [14]. Değer katmayan faaliyetler mamule doğrudan katkı sağlamadığı için ortaya çıkarılması daha kolaydır [15]. Değer katan ve değer katmayan faaliyetlerin belirlenmesi süreç analizi ile gerçekleştirilebilir. İşletmelerde değer katan faaliyetler belirlendikten sonra, değer katmayan faaliyetlerden kaçınılabilecek olanlar tespit edilip nasıl ortadan kaldırılabileceği belirlenmelidir. Ayrıca, değer katmayan ancak kaçınılamaz nitelikteki 
Aşağıdaki şekilde müşterinin katlandığı değer katan ve değer katmayan faaliyetler gösterilmiştir.

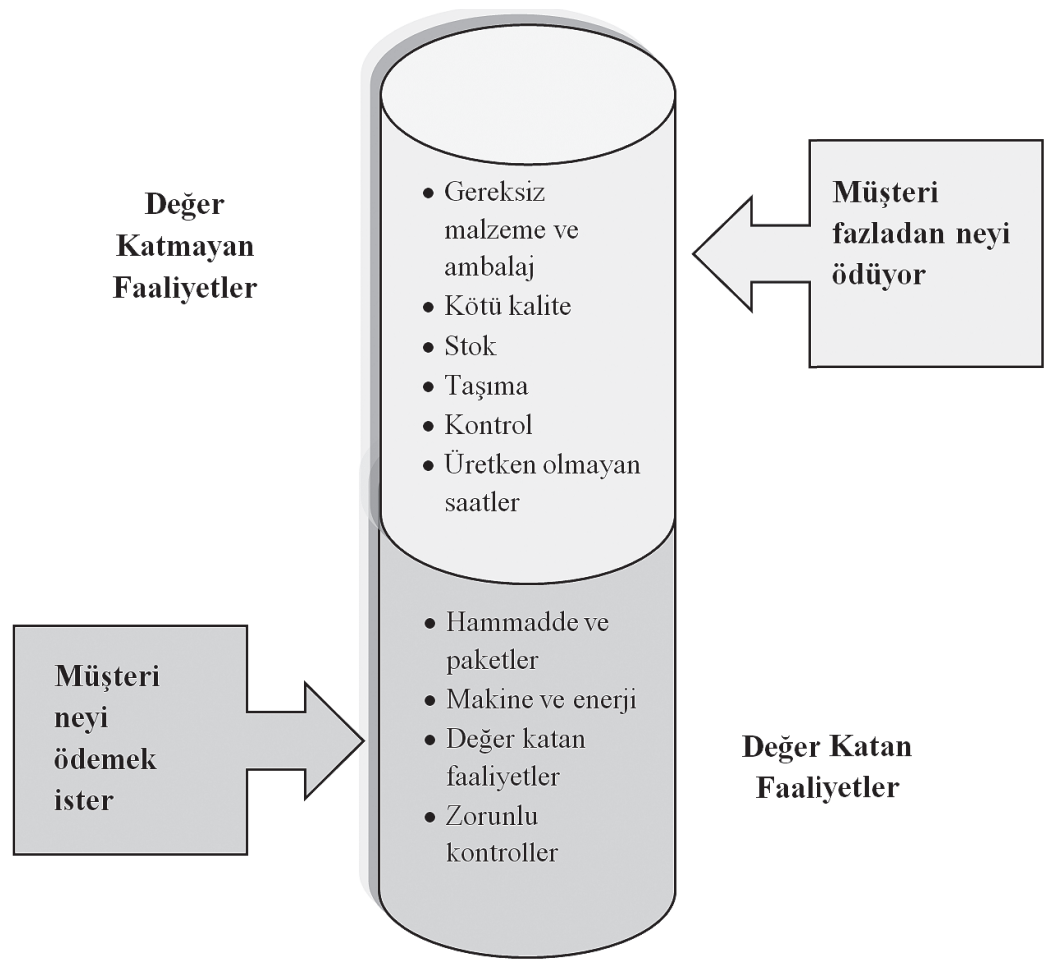

Şekil 1: Değer Katan ve Değer Katmayan Faaliyetler

Kaynak: Serpil Erol, “Yalın Yaklaşım ve Yalın Üretim”, Anahtar, Şubat 2012, s. 20.

faaliyetlerin iyileştirilmesi için gerekli çalışmaların yapılması gerekir. İyileştirme, değer katan ve katmayan tüm faaliyetlerde yapılmalıdır.

Süreç haritasını çıkarma, süreç analiz ve süreç analizini değerlendirme adımlarıdır. İşlem, sürecin bir parçası olup, hammadde veya yarı mamulün fiziksel yapısında veya konumunda bir değişiklik yaparak ona bir değer ekleyen birbirleriyle ilişkili faaliyetlerdir [16]. Değer analizi yaklaşımının kurucusu olan Lawrence D. Miles’e göre değer analizi, ürün, hizmet ya da bunlara ait süreçlere gerek maliyet gerek çaba açısından katkısı olmayan tüm faktörlerin tanımlanarak bunlarla bütünüyle sistematik olarak ilgilenen yöntemdir [17]. Değer akımı, belirli bir ürünün işletmedeki üç kritik yönetim işlevinden (problem çözme işlevi, bilişim yönetimi işlevi ve fiziksel dönüşüm-şekillendirme işlevi) geçirilmesi için gerekli olan tüm belli adımları gösterir [18].

Hastanelerde değer katmayan faaliyetler aşağıdaki tablodaki gibi örneklendirilebilir. 
Tablo 1: Hastanelerin Farklı Birimlerinde Değer Katan ve Değer Katmayan Faaliyetler

\begin{tabular}{|l|l|l|l|}
\hline Birim & Görev & Değer Katan Faaliyetler & Değer Katmayan Faaliyetler \\
\hline Ameliyat & Cerrah & Hastanın ameliyatı & Ameliyat öncesi prosedürler için bekleme \\
\hline Eczane & Eczacı & İlaç çalışmaları & $\begin{array}{l}\text { Hasta birimlerinden yeniden sürece dahil edilen } \\
\text { ilaçlar }\end{array}$ \\
\hline Yatan Hasta & Hemşire & Hasta ilaçlarının yönetimi & $\begin{array}{l}\text { Bilgisayardan ya da diğer sistemlerden bilgilerin } \\
\text { kopyalanması }\end{array}$ \\
\hline Radyoloji & $\begin{array}{l}\text { Rodyoloji } \\
\text { teknikeri }\end{array}$ & MR çekim süreci & Gereksiz yapılan çekim \\
\hline Laboratuar & Laborant & $\begin{array}{l}\text { Test sonuçlarının elde } \\
\text { edilmesi }\end{array}$ & Bozuk kitlerin tespit edilmesi \\
\hline
\end{tabular}

Kaynak: Mark Graban, Lean Hospitals: Improving Quality, Patient Safety and Employee Satisfaction, CRC Press, New York, 2009, p. 41.

Mamul üretim işletmelerinde üretim süreci dört temel zamana bölünerek belirlenebilir. Bunlar işleme, kontrol, aktarma ve bekleme zamanı olarak ifade edilebilir. Bu şekilde değerlendirildiğinde sadece işleme, değer katan faaliyet olarak kabul edilir [19]. Kontrol, aktarma ve bekleme için harcanan zamanların üretilen ürün ve hizmetlere herhangi bir değer katması söz konusu değildir.

Hastaneler için hizmet üretim süreci, üretim işletmelerine benzer bir yapıda teşhis ve tedaviyi kapsayan işleme, hastaların ve işlemlerin kontrolünü içeren kontrol, hastaların servislerden ameliyathane, görüntüleme merkezine veya başka bir birime taşınması ile alınan örneklerin laboratuara ulaştırılması ve hasta yatış ve çıkış işlemlerinde evrakların dolaşımı gibi süreçleri kapsayan aktarma ile hastaların kayıt, teşhis/tedavi için bekletilmesi ve tetkik sonuçlarının alınması için geçen süreçleri kapsayan bekleme zamanı olarak değerlendirilebilir. Hastanelerde hizmet üretim sürecinde değer katan faaliyetin, çıktıya göre değerlendirilmesi gerekmektedir. Buna göre, ayaktan teşhis ve tedavi için hastaneye başvuran bir hasta için değer katan faaliyetin, teşhis ve tedavi sürecindeki faaliyet olduğu söylenebilir. Laboratuar, görüntüleme, yatarak tedavi ve ameliyat için değer katan faaliyetlerin de yine yapılan hizmete ve çıktıya göre değerlendirilmesi gerekecektir.

İşletmelerin sürekli iyileştirme hedefine ulaşabilmeleri, süreç analizlerinin sürekliliği ile yakından ilgilidir. Süreç analizleri içinde en fazla katkı sağlayan oran ise üretim sürecinin etkinliği oranıdır. Üretim sürecinin etkinliği belirlenirken değer katan faaliyetler, değer katan ve değer katmayan faaliyetlerin toplamına bölünür. Oran l'e ne kadar yakınsa üretim sürecinin etkinliği o kadar fazladır [20]. Üretim sürecinin etkinliği oranının l'e yaklaşması değer katmayan faaliyetlerin minimize edildiğini gösterir.

Üretim süreci etkinliğinin arttırılabilmesi için üretim sürecinde ortaya çıkan israfların mümkün olduğu kadar azaltılması gerekir. Buradaki israf kavramı, hem değer katan faaliyetler sırasında hem de değer katmayan faaliyetler sırasında ortaya çıkan amaçsız kaynak tüketimlerini ifade eder. Aşağıdaki tabloda hastane işletmelerinde karşılaşılan israf türleri ve nedenleri özetlenmiştir. 
Tablo 2: İşletmelerde Meydana Gelen İsraflar, Nedenleri ve Hastane Örneği

\begin{tabular}{|l|l|l|}
\hline İsraf Türü & Açıllama & Hastane Örneği \\
\hline Kusurlar & $\begin{array}{l}\text { Yanlış işlem, yanlış kontrol ve hataların } \\
\text { düzeltilmesi için harcanan zaman }\end{array}$ & $\begin{array}{l}\text { Hasta durum kartının kaybedilmesi } \\
\text { sonucu yanlış hastaya, yanlış ilaç veya } \\
\text { yanlış dozda ilaç verilmesi }\end{array}$ \\
\hline $\begin{array}{l}\text { Gereğinden } \\
\text { fazla üretim }\end{array}$ & $\begin{array}{l}\text { Müşterinin ihtiyacından duyduğundan } \\
\text { daha fazla üretim yapmak }\end{array}$ & Gereksiz tanı işlemleri yapmak \\
\hline $\begin{array}{l}\text { Taşıma/ } \\
\text { Nakletme }\end{array}$ & Sistem içinde ürünün gereksiz hareketi & $\begin{array}{l}\text { Kayıt ve laboratuar arasında gereğinden } \\
\text { fazla yürümeye neden olan kötü } \\
\text { düzenleme }\end{array}$ \\
\hline Bekleme & $\begin{array}{l}\text { Gelecek işlem ortaya çıkana kadar } \\
\text { bekleme veya yeni faaliyet ortaya } \\
\text { çıkana bekleme }\end{array}$ & $\begin{array}{l}\text { Hastanın tedavi aşaması randevusu için } \\
\text { personelin tanı sonucunu beklemesi }\end{array}$ \\
\hline $\begin{array}{l}\text { Stoklar } \\
\text { Gereğinden fazla stok bulundurma } \\
\text { nedeniyle ortaya çıkan taşıma, } \\
\text { depolama vb. maliyetler }\end{array}$ & $\begin{array}{l}\text { İlaç ve tıbbi sarf malzemelerinin son } \\
\text { kullanma tarihinin geçmesi }\end{array}$ \\
\hline $\begin{array}{l}\text { Çalışan } \\
\text { hareketleri }\end{array}$ & $\begin{array}{l}\text { Çalışanların sistem içinde gereksiz } \\
\text { hareketleri }\end{array}$ & $\begin{array}{l}\text { Hatalı dizayn nedeniyle çalışanların } \\
\text { daha fazla hareket etmesi }\end{array}$ \\
\hline $\begin{array}{l}\text { Gereğinden } \\
\text { fazla işleme }\end{array}$ & $\begin{array}{l}\text { Müşteri için bir değer yaratmayan } \\
\text { işlemlerin yapılması }\end{array}$ & $\begin{array}{l}\text { Hiçbir zaman kullanılmayan hasta } \\
\text { formları }\end{array}$ \\
\hline $\begin{array}{l}\text { Çalışanların } \\
\text { yeteneklerinin } \\
\text { dikkate } \\
\text { alınmaması }\end{array}$ & $\begin{array}{l}\text { Çalışanların fikirlerinin dikkate } \\
\text { alınmaması ve kariyer gelişimlerinin } \\
\text { desteklenmemesi ile ortaya çıan kayıp } \\
\text { ve israflar }\end{array}$ & $\begin{array}{l}\text { Çalışanlar düşüncelerini içinde } \\
\text { saklanması vikirlerini kurumla } \\
\text { paylaşmaması }\end{array}$ \\
\hline
\end{tabular}

Kaynak: Graban, a.g.e., p. 43.

Yukarıda özetlenen israfların ortadan kaldırılması anlık olarak yapılabilecek statik bir durum değil, değer akımları belirlenerek zaman içinde ortadan kaldırılabilecek dinamik bir süreçtir. Bu kapsamda sürecin etkin bir şekilde sonuçlanması için değer akımlarının çok iyi belirlenmesi gerekir. Örneğin, hasta için değer akımı süreçteki değer katan ve değer katmayan tüm uygulamaları kapsar. Bu aşamada, hastanın tedavisi için gerekli tüm faaliyetleri kapsayan değer akım haritası hazırlanır. Bu harita istenilen sonucun elde edilmesi için uygulanması gereken tüm faaliyetleri içeren bir kılavuz görevi görür. Böylelikle üretim sürecinin iş akış şeması veya tüm bölümler ve bölümlerdeki objeler arasındaki ilişkiyi gösteren diyagramlar hazırlanabilir. Hasta değer akımı haritası oluşturmanın amaçları üç başlık altında kategorize edilebilir [21]:

- Hastaya gerçekten net bir şekilde değer katan faaliyetler

- İşe doğrudan değer katan, fakat hastaya çok az değer katan ya da hiç değer katmayan faaliyetler 
- Hastaya hiçbir şekilde değer katmayan faaliyetler

Hasta değer akım haritasında bu kategoriler sınıflandırıldıktan sonra öncelikle değer katmayan faaliyetleri ortadan kaldırma çalışmaları yürütülür. Değer katmayan faaliyetler arasında doğrudan ortadan kaldırılamayanlar için yeni bir süreç analizi yapılarak sürekli iyileştirmeye tabi tutulur. Son olarak değer katan faaliyetlerin süreç analizi yapılarak, gerçekleştirilebilecek iyileştirmeler belirlenir ve uygulamaya konur.

\section{HASTANEDE DEĞER KATMAYAN FAALIYETLER VE MALIYET YÖNETIMI}

Daha önce de vurgulandığı gibi değer katmayan faaliyetler, hastanede kaynak tüketimine neden olan ancak üretilen sağlık hizmetine herhangi bir değer katmayan faaliyetleri ifade eder. Değer akım haritalarıyla süreç ortaya konulduğunda, değer katan ve değer katmayan faaliyetler belirlenebilecek, bu aşamadan sonra ise, ortadan kaldırılabilecek ve iyileștirme yapılabilecek faaliyetler için gerekli çalışmalar yürütülebilecektir.

Çalışmanın izleyen kısmında, hastanede genel iş akış süreci ile değer katmayan faaliyetler belirlenerek bu faaliyetlerin nasıl ortadan kaldırılacağı veya iyileştirileceği analiz edilecektir.

Hastanelerde genellikle birbirinden bağımsız süreçler ve uzun bekleme sıraları ile karşılaşılmaktadır. Neredeyse Türkiye'deki tüm hastanelerin ortak sorunu olarak kabul edilebilecek bu durumun ortaya çıkmasındaki sorunlardan biri, sağlık hizmeti yöneticilerinin maliyet ve süreç yönetimi konusunda yeterince hassas davranmamasıdır. Bunun bir sonucu olarak da hastanelerde birbirinden bağımsız süreçler ve değer katmayan faaliyetler ortaya çıkmaktadır. Hastanelerde etkin ve yalın bir süreç oluşturmak, maliyetlerin yönetilebilmesi ile yakından ilişkilidir. Maliyet yönetiminin etkinliliği ise verimlilikle doğru orantılıdır.

Hastanede kapasite planlaması, iş akış ve faaliyet süreçleri dikkate alınmadan yapıldığında, hastanın tanı ve tedavi sürecinde, bu sürece katkı sağlamayan faaliyetler ortaya çıkabilmektedir. Hastanelerde değer katmayan faaliyetlerin ortadan kaldırılması ve tüm faaliyetlerin iyileştirme süreci, tüm süreçlerin göz önüne alındığı değer akış analizi ile başlar. Yapılan bu analiz sonucunda hastaya doğrudan değer katan ve değer katmayan faaliyetler birbirinden ayrıştırılabilir. Bu analiz, değer katmayan faaliyetlerin kaçınılabilecek olanlarının ortadan kaldırılmasına, kaçınılamayacak olan faaliyetlerin ise ise iyileştirilebilmesine imkan sağlayacaktır. Ayrıca bu analiz, değer katan faaliyetlerin de iyileştirilebilmesi için önemli bir başlangıç noktası olarak değerlendirilebilir.

Değer analizinin başlangıcında öncelikle hastanede tüm süreçleri içeren, kapsamlı bir iş akış süreci belirlenmelidir. Bu süreç, hastanın hastaneye çeşitli yollarla başvurmasıyla başlayacak, çeşitli süreçlerden geçerek teşhis ve tedavi işlemleri gerçekleştirilerek, sevk ve çıkış işlemleri ile son bulacaktır. Şekil 2'de hastane genel iş akış süreci verilmiştir. 


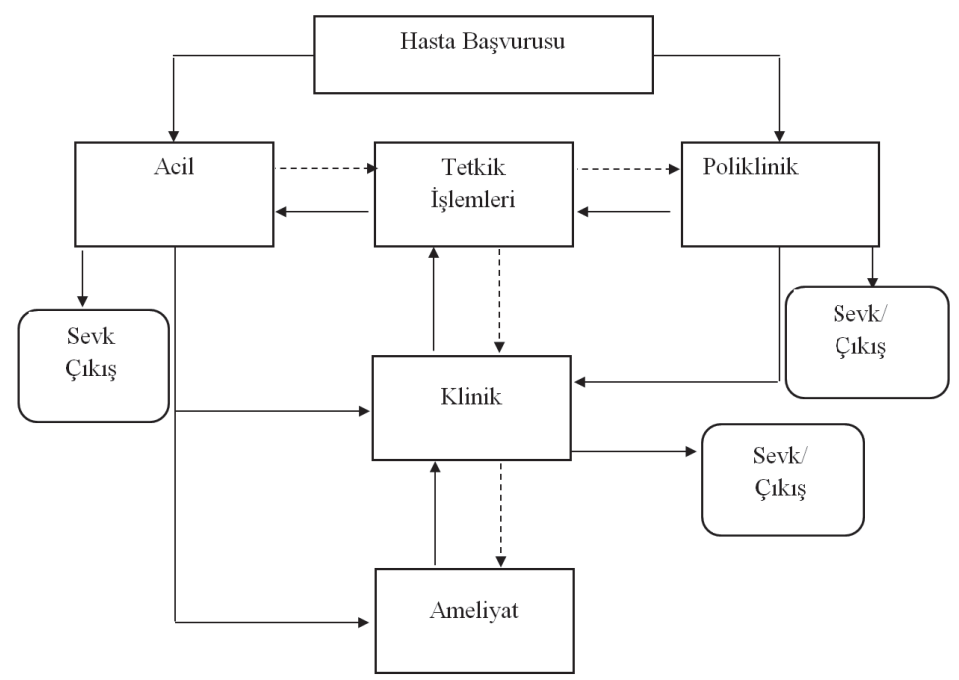

Şekil 2: Hastane Genel İş Akış Süreci

Yukarıdaki şekilde de görüldüğü gibi hastanede süreç, hasta başvurusu ile başlamaktadır. Hastanın hastaneye başvurması acil servis ya da polikliniğe giriş yaparak gerçekleşmektedir. Acil servise ya da polikliniğe başvuran hasta, bu aşamada ya gerekli muayene yapılarak sevk ve çıkış işlemine ya da detaylı inceleme yapılmak üzere laboratuar, görüntüleme merkezi gibi tetkik işlemlerinin yapıldığ rak tedavisine, ameliyata alınmasına ya da başka kurumlara sevk edilmesine veya çıkışına karar verilmektedir. Ameliyata ya da yatarak tedaviye karar verilmesi yeni süreçlerin başlangıcıdır.

Tarafımızdan hazırlanan değer akım haritalarından elde edilen bilgiler, hastanede önemli ölçüde değer katmayan faaliyetin ve buna bağlı olarak israfın varlığını ortaya koymuştur. Bütün olarak değerlendirildiğinde hastanede israfa neden olan ve değer katmayan faaliyetlerin gereksiz beklemelerden, gereğinden uzun süreçlerden, personelin değersiz hareketlerinden, değersiz taşımalardan, fazla üretimden ve stoktan kaynaklandığ belirlenmiştir. Bu değer katmayan faaliyetler ve bunların ortadan kaldırılması/iyileştirilmesi için yapılması gerekenler aşağıda özetlenmiştir.

\section{III.1. Değer Katmayan Beklemeler}

Hastanede değer katmayan en önemli unsurlardan biri, beklemelerdir. Bu beklemeler hastanın beklemesi, üretilen tıbbı hizmetlerin beklemesi ve personelin beklemesi olarak sıralanabilir.

Hastanede iyi tasarlanmamış kayıt ve işlem süreçleri nedeniyle, hastalar bekletilmektedir. $\mathrm{Bu}$ beklemelerin büyük bir kısmı kayıt ve birbirinden bağımsız sayılabilecek işlem süreçlerinden 
kaynaklanmaktadır. Örneğin servise yatacak olan bir hastanın, önce kayıtta beklemesi, sonra muayene sırası beklemesi ve yatış kararı alındıktan sonra boş yatak beklemesi hastaya değer katmayan beklemelerdir. Eğer burada bilişim teknolojisine dayalı bir randevu, kayıt ve hasta takip sistemi kullanılırsa önemli ölçüde azaltılabilecektir.

Hasta takip sistemi, bu beklemeleri azaltmanın yanında hasta güvenliği, süreç analizleri ve maliyetlerin zamanında ve doğru olarak hesaplanmasına da katkı sağlayacaktır. Hastaların takibinde, hasta bileklik sistemi kullanılabilir. RFID (Radio-Frequency Identification) okuyuculu bu bileklikler, hastaların ve sürecin takibinde önemli avantajlar sağlayacaktır.

Hasta takip sisteminin hasta güvenliğine katkısı şu şekilde olacaktır: Hastaya verilecek ilaçlar ve dozları hasta takip sistemi üzerinden elektronik olarak tanımlandığında, ilacı verecek hemşire hasta bilekliğini okuttuğunda, hastaya hangi ilaç verilecekse sadece verilmesi gereken ilacın bulunduğu bölüm açılacağından, hastaya doğru dozda doğru ilacın verilmesine katkı sağlayacaktır. Hasta takip sistemi, aynı zamanda yemek takibinde de kullanılabilir. Diyet menü yazılan bir hastanın hasta bilekliği okutulduğunda, hangi menünün verileceğini otomatik gösterileceği için hastaya, bu menü dışında başka bir menü verilme riski ortadan kalkabilecektir.

Hasta takip sisteminin maliyetlerin zamanında ve doğru olarak hesaplanmasına katkısı şu şekilde olacaktır: Hastanın hangi ilaçtan ne kadar aldığı, hangi tahlilleri yaptırdığı, hangi odada ne kadar süre kaldığı, hangi doktorun ne kadar süre muayene ettiği, hangi yemeklerden yediği kolaylıkla ve anlık olarak belirlenebilir. Böylece hastaları, doktorları ve bölümleri kıyaslama gibi maliyet temelli performans ölçümleri yapılabilir. Hasta bilekliği kullanımı, maliyetlerin önemli bir kısmının doğrudan ve zamanında hastaya yüklenmesine imkan sağlayacaktır.

Hasta takip sisteminin süreç analizine sağladığı fayda ise şu şekildedir: Hastanın hangi birimlerde bulunduğu, ne kadar süre beklediği, ne kadar mesafe hareket ettiği belirlenebildiği için süreç haritalarının çıkarılmasına katkı sağlayacaktır.

Çalışmamıza konu olan hastanede hastalar, bir sonraki işleme geçebilmek için önceki işlemlerin tamamlanmasını beklemektedir. Örneğin kan tahlili yaptırmak isteyen bir hastanın, diğer hastaların kitlerini beklemek zorunda kalması veya birden fazla sorumluluk verilen personelin diğer görevini yaparken beklenilmesi, hizmetin gereksiz beklenmesine neden olmaktadır.

Hastanede karşılaşılan diğer bir bekleme ise çalışanların beklemesidir. Personelin beklemesi genellikle, süreçlerin uygun olmayan dizaynından kaynaklanmaktadır. Ameliyata girecek olan doktorun, ameliyat malzemeleri sterilize edilmediği için ameliyata başlayamaması bu duruma örnektir. Buna benzer durumların önlenmesi için süreçlerin uygun şekilde yeniden dizayn edilmesi ve hastane içinde yatay ve dikey olarak iyi bir bilgi iletişim sisteminin kurulması, personelin değer katmayan beklemelerini ortadan kaldırılabilecektir.

Yalın perspektiften bakıldığında hastanelerde yürütülen faaliyetlerin çok büyük bir kısmını değer katmayan faaliyetlerin oluşturduğu görülecektir. Aşağıdaki şekilde bir hastanın tedavi 
için gittiği hastanede genel iş süreci gösterilmiştir. Yaklaşık 31 hafta süren ve toplam hastanede 610 dakika geçiren bir hastanın tedavisi için değer katan faaliyetin sadece 100 dakika olduğu belirlenmiştir. Bu sürenin dışında harcanan zamanın tamamı hastaya değer katmayan faaliyetlerden oluşmaktadır [22].

\section{III.2. Değer Katmayan Gereğinden Fazla Süreç}

Değer katmayan gereğinden fazla süreç, gerçekleştirilmek istenen işlemin katkı sağlamadığı halde uzatılmasıdır. Değer katmayan gereğinden fazla sürecin ortaya çıkması genellikle hastanedeki çalışanlar veya departmanlar arasındaki iletişim eksikliğinden kaynaklanmaktadır. Örneğin doktor tüberküloz hastasından röntgen filmi istediğinde bunu göğüs filmi olarak tanımlar. Fakat radyoloji hastasının filmi de göğüs filmi olarak tanımlanmaktadır. Bu durumda radyoloji teknisyeni tüberküloz hastasının filmini, radyoloji hastası gibi çektiğinde 8 dakikada çekilecek röntgen 30 dakikada çekilmiş olacaktır. 22 dakikalık süre ne hastaya, ne doktora, ne de hastaneye herhangi bir fayda sağlamadığı halde gereksiz yere harcanacaktır.

Gereğinden fazla sürece ilişkin benzer bir durum satınalma bölümünde yaşanmaktadır. Satınalma bölümünde gerçekleştirilen bir işleme ilişkin dosyaların dört kopyası alınarak bunlar satın alma şefi, başhekim yardımcısı, başhekim ve hastane müdürü tarafından kontrol edilmektedir. Bu kontrollerin büyük bir kısmı, sürecin gereğinden fazla uzamasına neden olmaktadır. Başhekim yardımcısı ve başhekimin yaptığı kontrol, satınalma sürecine önemli bir değer katmamaktadır. Etkinliği artırmak için bu kontrollerin, iç denetim birimi tarafından gerçekleştirilmesi daha uygun olacaktır.

\section{III.3. Personelin Değer Katmayan Hareketleri}

Personelin değer katmayan hareketleri personelin gereksiz yere yorulması, gereğinden az dinlenmesi, hastaya daha az zaman ayırması gibi sorunlara neden olmaktadır. Bu durum genellikle çalışanların gereksiz uzun yürüyüşlerinden kaynaklanmaktadır. Klinikte yatan hastanın laboratuardan kan tahlili sonucunu almak için hastane görevlisinin hasta yakınına eşlik etmesi, binanın yanlış tasarımı nedeniyle ilgili birimler arasındaki mesafenin uzunluğundan kaynaklanan yürüyüşler personelin değer katmayan hareketine örnektir.

Personelin değer katmayan hareketlerini ortadan kaldırmak için öncelikle, hastane personeli elektronik yaka kartı sistemine dahil edilebilir. Bu sistem sayesinde süreç analizlerini gerçekleştirmek de kolaylaşabilecektir. Çünkü bu kart sistemi sayesinde çalışanların nerede, ne kadar süre, hangi departmanda, ne için zaman harcadığı tespit edilebilecektir. Böylelikle planlama daha etkin bir şekilde yapılarak, performans ölçümleri gerçekleştirilir ve çalışanların mesai saatlerini farklı yerlerde geçirmesine engel olunur. Bu uygulama özellikle döner sermaye payları performansa bağlı olarak verildiği için daha adil ve şeffaf bir gelir payı dağıtımına katkı 
sağlayacaktır. Ayrıca hastane içinde acil durumlarda, en yakın ve boştaki personelin hastaya yönlendirilmesi de mümkün olabilecektir. Bazı hastanelerde personelin devamının izlenmesi için kart, kamera ve parmak izi okuyucu ile desteklenen "personel devam kontrol sistemi” uygulanmaktadır. Bu sistem, personelin hastaneye giriş ve çıkış saatlerini kontrol etmekte, ancak personelin etkin ve verimliliğini artırmada yetersiz kalmaktadır.

Personelin değer katmayan gereksiz hareketlerinin önlenmesinde, hastane binasının planlanması da etkili unsurlardan biridir. Hastanenin kuruluşu aşamasında, servislerdeki hemşire odasının koridorun başı ya da sonu yerine merkezde yer almasına dikkat edilmesi, gereksiz yürümeleri önleyebilecektir. Böylelikle hemşireler daha kısa sürede, daha az yürüyerek hastaya veya ilgili malzemelere ulaşabilecektir.

\section{III.4. Değer Katmayan Taşımalar}

Değer katmayan taşımalar, tıbbi malzemelerin, sonuçların veya hastaların gereksiz şekilde sistem içinde yer değiştirmesinden kaynaklanmaktadır. Bu durum hastaya zamanında müdahale edilememesine, taşıma sırasında malzemelerin kaybolmasına ya da bozulmalara neden olabilir. Örneğin ameliyat odası ile sterilizasyon odasının arasında mesafe olması, ameliyatta kullanılan aletlerin ve malzemelerin gereksiz yere taşınmasına, kaybolmasına ve hassas muhafaza ihtiyacı olan bazı aletlerin bozulmasına neden olabilir. Yine tanı ve teşhis için kullanılan örneklerin laboratuara, laboratuarda analiz edilen örnek sonuçlarının da servislere taşınması, hem gereksiz harekete hem de gereksiz taşımaya neden olmaktadır. Aynı zamanda görüntüleme sonuçlarının elektronik ortamda doğrudan doktora iletilmemesi de gereksiz taşıma ve harekete neden olmaktadır. İlaçların ecza deposundan servislerdeki hastalara adet adet taşınması da yine gereksiz hareket ve taşımaya neden olan faaliyetlerdendir.

Gereksiz taşımaların ortadan kaldırılması için öncelikle hastane süreçlerinin uygun şekilde dizayn edilmesi gerekmektedir. Sterilizasyon merkezinin ameliyathanenin içinde bulundurulması ya da portatif sterilize cihazlarının ameliyat odasında bulundurulması gerekir. Sterilizasyon merkezinin ameliyathanede bulunması, ameliyathaneye bilinçli ve yetkili ekip girebildiği için bu durum aynı zamanda hasta güvenliğine de katkı sağlayacaktır. Örneklerin taşınması ve analiz sonuçlarının ilgili yerlere ulaştırılmasında, pnömatik tüp sisteminin kullanılması, gereksiz taşıma ve hareketleri ortadan kaldırmak için uygun bir çözüm olarak kabul edilebilir. Kullanılan pnömatik tüp sistemi, acilden gelen örnekleri öncelikle taşıyacak şekilde tasarlanmalıdır. Görüntüleme sonuçları ise doktora elektronik ortamda ulaştırıldığında doktor hem daha ayrıntılı, hem de daha kısa bir sürede teşhis ve tanı işlemini gerçekleştirebilecektir. Böylelikle acil olan hastalara zamanında müdahale edilebilecek ve gereksiz taşıma ve hareketler ortadan kaldırılabilecektir. Ayrıca doktor, ek uzman görüşüne ihtiyaç duyduğunda elektronik ortamdan çok kısa zamanda ilgili kişi veya birimlerle iletişim kurabilecektir. 


\section{III.5. Gereğinden Fazla Hizmet Üretimi}

Gereğinden fazla üretim, hastaların ihtiyacını aşan ve hastalara fayda sağlamayan hizmetin üretilmesidir. Bu durum hastanede özellikle fazla ilaç ve malzeme kullanılması, gereğinden fazla tetkik istenmesi gibi durumlarda ortaya çıkmaktadır. Örneğin hastanede tam zamanlı stok politikası benimsenmemesinin bir uzantısı olarak, servislere gereğinden fazla ilaç gönderilmesi ve kullanılmayan ilaçların geri iadesi, hem gereğinden fazla hizmet üretimine, hem de gereksiz taşıma, gereksiz stok ve gereksiz harekete neden olmaktadır.

Gereğinden fazla hizmet üretimi, sürecin yalınlaştırılması ile önlenebilir. Bu da ihtiyaç ortaya çıktığında hizmet üretimin gerçekleştirilmesi ile sağlanabilir. Doktor tarafından istenilen tahlillerin gereğinden fazla olması veya laborantların gereğinden fazla işlem yapması, değer katmayan hizmet üretime neden olmaktadır.

Servislerde bulunan malzeme dolaplarının emniyet malzeme miktarları belirlenerek ihtiyaca göre malzemelerin gönderilmesi sağlanmalıdır. İlaç yönetiminde etkinliği sağlamak için tek doz ilaç yönetim sistemine (PYXIS) geçiş yapılabilir. Entegre yazılıma sahip bu sistem, gereğinden fazla hizmet üretiminin azaltılmasına katkı sağlayacaktır. Tek doz ilaç yönetim sistemleri, talep geldiğinde ilaçları istenilen dozda bölümleme özelliğine sahiptir. Bu sistem, Amerika’daki bazı hastanelerde olduğu gibi kullanılan ilaç servis arabalarıyla entegre hale getirildiğinde sistemin etkinliği artacaktır. İlaç servis arabalarının işlevi, doktor hastaya uygulanması gereken ilacı ve dozu sisteme girdiğinde talep, tek doz ilaç yönetim sistemi tarafından algılanarak gerekli dozlar insan eli değmeden bölümlenerek ilgili hastanın haznesine yüklenmektedir. Hemşire ilaç servis arabasıyla hastanın odasına geldiğinde, hasta bilekliği okutularak sadece ilgili hazne açılmakta ve hastaya yanlış ilaç veya yanlış doz verme olasılığı önemli ölçüde azalmaktadır. Burada değer katmayan hizmet üretimi ortadan kalkarken, değer katmayan hareket ve taşımanın arttığı düşünülebilir. Fakat bu sistemler kullanıldığında eczaneye gereksiz ilaçların geri dönmesi için gerçekleştirilen taşımanın, geri dönen ilaçların yerleştirilmesi için geçen zamanın, ilaçların manuel olarak bölümlendirilmesinde harcanan zamanın ve hastaya yanlış ilaç ve doz verildiğinde ortaya çıkan yeni tedavi sürecinde tüketilen kaynakların ve zamanın dikkate alınması gerekir.

\section{III.6. Gereğinden Fazla Stok}

Gereğinden fazla stok, genellikle çok yüksek miktarda alım yapılarak ihtiyaç duyulandan fazla ilaç ve tıbbi malzeme bulundurmaktan kaynaklanmaktadır. Çok yüksek miktarda alım yapıldığında, ilaçların ve tıbbi malzemelerin son kullanma tarihi geçebilir, ilacın bilinmeyen yan etkileri ortaya çıktığında ilacın kullanımı yasaklanabilir. Gereğinden fazla stok ayrıca gereksiz barkod kullanılmasına, gereğinden fazla depolama ve elde bulundurma maliyetine neden olacaktır. Hastane nakit varlıklarını stoğa bağladığı için paranın zaman değerinden dolayı da kayıp ortaya çıkacaktır. Bununla birlikte birçok sektörde ideal bir yapı olarak ifade edilen tam zamanlı envanter yöntemini, hastane de sıfır stok politikası olarak uygulamak bazı riskleri beraberinde getirmektedir. Acil müdahale gereken durumlarda hastanede ilaç ya da tıbbi malzemenin 
transferini beklemek, telafisi mümkün olmayan sonuçlara neden olabilir. Ayrıca sağlık sektöründe tedarikçilerle tam anlamıla bir güven oluşturulması, mevcut yapıda oldukça zordur.

Hastanelerde uygun yaklaşım, emniyet stok miktarına göre stok bulundurulmasıdır. Emniyet stok süresi belirlenirken, alım aşamasında gerçekleştirilecek ihale süresi de dikkate alınmalıdır. Hastanelerde ihale süreci 45-60 gün arasında tamamlanmaktadır ve tedarik süresi hesaplanırken bu süreç göz ardı edilmemelidir. Burada emniyet stok miktarının altında stok bulundurup risk almak yerine ihale süreci, dosya hazırlık süreci, piyasa araştırmaları ve onay süreci kısaltılarak emniyet stok miktarı ve süresi düşürülebilir. Stokların gereğinden fazla olup olmadığ edilirken değerli stoklar için elektronik barkod sistemi kullanılması, analizlerin daha sağlıklı yapılmasına imkan verecektir. Elektronik barkod kullanılması, maliyeti arttırıcı bir unsur olarak düşünülse de stok sayım sürelerinin kısalması, bozulma ve kaybolmaların önlenmesi gibi faydaları ortaya çıkaracaktır. Böylelikle değer katmayan faaliyetler azaltılarak süreç kısaltılacak, stok kontrol hakimiyeti artarak, hata ve hile payı azalacaktır. Burada kullanılan personelin ücreti ile hata ve hile nedeniyle yaşanacak kayıplar, elektronik barkodlama sisteminin maliyetinden daha fazla mı, yoksa daha düşük mü olduğu, fayda-maliyet analizi yapılarak belirlenebilir.

\section{SONUÇ}

Çalışmamamıza konu olan hastanede, yalın düşünce ilkelerinin uygulanmaması önemli düzeyde israfın ve değer katmayan birçok faaliyetin ortaya çıkmasına neden olmaktadır. Yapılan incelemeler sonucunda hastanede gereksiz hasta ve personel beklemelerinin, ilaç ve malzeme taşımalarının, hasta ve personel hareketlerinin, stok bulundurmanın, gereğinden fazla hizmet üretiminin değer katmayan faaliyetlere neden olduğu saptanmıştır. Süreçlere ilişkin değer akım haritasından elde edilen sonuçlardan yola çıkılarak, hastaya sunulan hizmetin iyileştirilmesi için yapılması gerekenler ile bu iyileştirmeyi destekleyecek araçlar sıralanmıştır. Bu iyileştirme sürecine katkı sağlayan bilişim ve otomasyon teknolojisine bağlı araçlar; hasta bilekliği, hasta ihtiyacına yönelik tercih edilen cihazlar, elektronik orderlar, elektronik yaka kartları, hasta takip sistemi, elektronik barkodlamaya sahip stoklama sistemi, PYXIS ilaç yönetim sistemi ve tüm bunlarla entegre bir hastane bilgi sistemi olduğu belirlenmiştir. Bunlarla birlikte bahsedilen araçları organize edebilecek uzman bir yönetim ekibine ihtiyaç olduğu tespit edilmiştir. Çalışmamızda hastanede değer katmayan faaliyetlerin ortadan kaldırılmasına ve tüm faaliyetlerin yalınlaştırılarak iyileștirilmesine yönelik yapılması gerekenler ve uygulamaya konulacak yalın çözümlere, ilgili değer katmayan faaliyetler kapsamında vurgu yapılmıştır.

Hastanede değer akım haritası analizine dayanılarak ulaşılan sonuçlara göre, değer katmayan faaliyetlerin hizmet sürecinin yavaşlamasına ve uzamasına, katlanılan maliyetlerin yanlış hesaplanmasına, hasta memnuniyetinin azalmasına, yanlış ücret politikaları uygulanmasına, hata ve hilelerin artmasına, çalışanların performanslarının düşmesine, kaynakların gereksiz yere tüketilmesine veya gereksiz yere dönüştürülmesine, yanlış tanı ve tedavi hizmetlerinin sunulmasına ve potansiyel hastalara hizmet sunulamamasına neden olduğu belirlenmiştir. 


\section{Yararlanılan Kaynaklar}

[1] Yüksel, H. (2013). Hastane Laboratuvarlarında Yalın Düşünce İlkelerinin Uygulanması, Yalın Dönüşüm, 6. Endüstri Mühendisliği Bahar Konferanslar, TMMOB Makine Mühendisleri Odas1, 4-6 Ekim. İzmir, (http://www.mmo.org.tr/resimler/dosya_ekler/ 27d3714567e0a1e_ ek.pdf). [17.02.2014]. 1-10.

[2] Şimşir, İ. \& Bağış, M. vd. (2013). Sağlık Hizmetlerinde İsraf Yönetimi. IV. Uluslararası Sağlıkta Performans ve Kalite Kongresi. 01-03 May1s. Ankara. 21-38.

[3] İncesu, E. (2013). Yalın Sağlık: Sağlık İşletmelerinde Yalın Yönetim Anlayışı, 7. Ulusal Sağlık ve Hastane İdaresi Kongresi. 27-29 Eylül. Konya. 1-9.

[4] Gökçen, G. (2004). Faaliyet Tabanlı Maliyetlemenin İşletme Kararlarında Kullanılması. Muhasebe ve Finansman Dergisi. Sayı: 23. Temmuz. 58-67.

[5] Womack, J. P. \& Jones, D. T. (1998). Yalın Düşünce. (Çev: Nesime Aras). Sistem Yayıncılık: İstanbul.

[6] Carreira, B. (2005). Lean Manufacturing That Works. AMACOM: New York.

[7] Hansen, D. \& Mowen, M. \& Guan, L. (2009). Cost Management: Accounting \& Control. 6 Th. Ed. South-Western Cengage Learning: USA.

[8] Kaplan, R. S. \& Cooper, R. (1998). Cost \& Effect: Using Integrated Cost Systems to Drive Profitability and Performances. Harvard Business School Press.

[9] Kimmel, P. D. \& Weygandt, J. \& Kieso, D. E. (2009). Accounting: Tools for Business Decision Making. John Wiley\&Sons Inc.: USA.

[10] Carreira, B. (2005). Lean Manufacturing That Works. AMACOM: New York.

[11] Kaplan, R. S. \& Cooper, R. (1998). Cost \& Effect: Using Integrated Cost Systems to Drive Profitability and Performances. Harvard Business School Press.

[12] Şakrak, M. (1997). Maliyet Yönetimi. Yasa Yayınları: İstanbul.

[13] Şakrak, M. (2002). Değer Katmayan Faaliyetlerin Maliyet Yönetimindeki Önemi. Mali Çözüm. Sayı: 61. Ekim- Kasım-Aralık.

[14] Şakrak, M. (2002). Değer Katmayan Faaliyetlerin Maliyet Yönetimindeki Önemi. Mali Çözüm. Sayı: 61. Ekim- Kasım-Aralık.

[15] Kaplan, R. S. \& Cooper, R. (1998). Cost \& Effect: Using Integrated Cost Systems to Drive Profitability and Performances. Harvard Business School Press.

[16] Yıldıztekin, İ. (2011). Maliyet Kontrolü İçin Faaliyet Analizi, Atatürk Üniversitesi İktisadi ve İdari Bilimler Dergisi. Cilt: 25. Sayı: 3-4. 181-211.

[17] Duran, C. (2007) Değer Analizinin Uygulama Süreci. Kamu-Iss. Cilt: 9. Sayı: 3. 81-96. 
[18] Şakrak, M. (2002). Stratejik Maliyet Yönetimi: Bilgi Sistemi ve Yalın Düşünce. Yaylım Yayınc1lık: İstanbul.

[19] Şakrak, M. (1997). Maliyet Yönetimi. Yasa Yayınları: İstanbul.

[20] Şakrak, M. (2002). Değer Katmayan Faaliyetlerin Maliyet Yönetimindeki Önemi. Mali Çözüm. Sayı: 61. Ekim- Kasım-Aralık.

[21] Chalice R. (2005). Stop Rising Healthcare Costs Using Toyota Lean Production Methods, Quality Press: Milwaukee.

[22] Jones, D. \& Mitchell A. (2006). A. Lean thinking for the NHS. London.

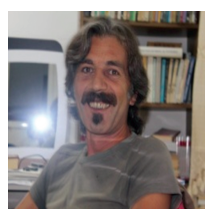

İrfan ÖZEN - ozenirfan@gmail.com

İrfan ÖZEN has Ph.D of Acounting-Finance at Marmara University, Social Sciences Institute. $\mathrm{He}$ is lecturer at Muğla Sıtkı Koçman University. His research areas are cost acounting, cost management, and hospital cost. 
